\title{
HUNGARIAN COUNTIES AND REGIONAL DEVELOPMENT - CHANGING ROLES IN A TRANSFORMING ENVIRONMENT
}

\author{
István HOFFMAN ${ }^{\mathrm{a}}$ \\ a Eötvös Loránd University (Budapest), Faculty of Law, Department of Administrative Law, \\ hoffman.istvan@ajk.elte.hu
}

Cite this article: Hoffman, I. (2018). Hungarian Counties and Regional development - Changing Roles in a Transforming Environment.' Deturope. 10(3), 162-179

\begin{abstract}
The main aim of this jurisprudential analysis is to review the transforming regulation and practice on the regional development tasks of the Hungarian county governments. The main European models of the regional $\left(2^{\text {nd }}\right.$ or $3^{\text {rd }}$ tier) municipalities will be reviewed by the article. Traditionally, the county municipalities have had an important role in the Hungarian public administration. The changing role of the counties in the development policies will be analysed, as well. Although this role was weakened after 1990, the new county governments have had significant service provider competences until 2011, but their development tasks were just partial. This system has been transformed by the new Hungarian Municipal Code. The counties lost the majority of their functions and they received competences in regional planning and development. These tasks were extended by the reforms between 2013 and 2016. These changes could be the base of a new "developer county" approach.
\end{abstract}

Keywords: Hungary, counties, regional development, legal regulation, municipal tasks, municipal reform

\section{INTRODUCTION AND METHODS}

Hungary - similarly to other countries - has a two-tier municipal system. These $2^{\text {nd }}$ tier municipalities have traditionally important competences in the field of regional planning and development. Although the counties have these competences, the scope of them is a changing one. Different models have evolved and the approach of the development tasks of the counties have transformed several times.

In Hungary the legal status and the role of the county governments have been significantly changed by the reforms between 2011 and 2017. A new model was chosen by the Act CLXXXIX of 2011 on the Local Self-Governments of Hungary (hereinafter: Mötv). The regional planning and development tasks became the major competences of the counties.

In this article the administrative reform of the counties will be reviewed. Firstly, the methods of the analysis will be introduced. Secondly, the background of the Hungarian regulation will be analysed: the main models of the county governments and their role in 
development policies and the evolvement of the Hungarian regulation and administrative practice will be presented.

The approach of this analysis will mainly be jurisprudential, to show how the legal regulation on the development competencies of the county governments transformed. Although the major approach will be jurispudential, comparative methods will be used in the second part of the article. The approach of the administrative sciences will be used, as well, because the administrative practice will be - at least partially - analysed by this article.

\section{THEORETICAL BACKGROUND: MAIN MODELS OF THE LEGAL STATUS OF THE COUNTY GOVERNMENTS AND THE CHANGES OF THE HUNGARIAN LEGISLATION ON THE COUNTIES}

The main models of the county governments should be analysed to understand the Hungarian regulation and its transformation. Firstly, the (traditional) Anglo-Saxon model will be reviewed which is based on the enumeration of the local government powers and duties. Secondly, the approach of the Continental countries will be examined which is based on the general clause of the local government tasks.

\section{The (traditional) Anglo-Saxon model}

The county governments in England were defined traditionally as public entities established by the Parliament (Bailey, 1983, p. 8). Thus, the powers and duties of the local governments are based on an enumeration of the legislation (Morphet, 2008, p. 40), the limit of their powers are defined by the ultra vires principle (Arden, Baker, \& Manning, 2009, pp. 305308). The local government system of the United States is based on the ultra vires principle but this traditional regulation rule has been transformed by regulation of the constitutions of the states. The ultra vires approach of the competences of the local governments transformed significantly in the last decades. Not only the American but the Canadian, Australian and Irish model has been changed and the general powers of the English municipalities was recognised by the Localism Act 2011 (Elliott \& Thomas, 2017, p. 318).

In the traditional Anglo-Saxon local government systems the counties - and the county towns (or unitary authorities) - are the most important local authorities. In the United Kingdom the counties are responsible for a wide range of public services (Arden et al., 2009, 3-5). Similarly, in Ireland the counties are the main local authorities (O'Sullivan, 2003, 4647). Although several important tasks are performed by the special authorities and the school districts, and the county system is spatially strongly fragmented, the county councils could be 
considered as the base of the American local government system (Bowman \& Kearney, 2012, pp. 272-274). Thus, the main tasks are performed by these entities. The urbanization transformed this structure: a convergence of the county and metropolitan governments can be observed which is caused mainly by the large suburban areas and the urban agglomerations (Clawson, 2011, 163-164). In the United States the counties (and the city governments) are the main bodies responsible for regional planning and development, but the special districts could have important development competences, as well (Bowman \& Kearney, 2012, pp. 277-280).

In the field of regional development, the regulation of the United Kingdom and Ireland transformed significantly in the last decades. After the Accession to the European Union the regional development of these countries changed. In England regions were established and regional development agencies were institutionalised. The regionalisation of England was broken after 2010, because these bodies were abolished, and now the counties, the unitary authorities and several agencies of the central government are responsible for these tasks (Cowie et al., 2016, p. 143) In Ireland special boards have been organised and in the 1990s two regional assemblies were established which has been responsible for the major development tasks. These entities could be interpreted as a speical form of inter-municipal cooperation, because the members of these bodies are delegated by the county and town governments and other municipalities (Callanan, 2003, pp. 437-438). Therefore, the traditional Anglo-Saxon approach changed significantly: the general powers of the municipalities has been widely recognised and a regionalisation tendency could be examined in the European Anglo-Saxon countries.

\section{The role of the regional (second- or third-tier) local governments in the countries of the continental Europe}

A common element of the local government systems of the continental Europe is that the powers of the local government system are defined by a general clause, which are mainly the "local public affairs" or "local affairs".

Although the general clause is common, the constitutional status of the second- or thirdtier local governments is different. Typically, the powers of the county governments are defined by the general clause regulated by the national constitutions. Thus these local governments have general powers. This model is followed, for example, by France where the county governments (département) can be considered as authorities with general powers (Bernard, 1983, pp. 15, 122-123). A different regulation has been evolved in Germany. 
Although a general clause model is established by the article 28 paragraph 2 of the German Constitution (Grundgesetz, hereinafter $G G$ ), this general responsibility is guaranteed for the settlement level municipalities, for the communities (Gemeinde) and for their inter-municipal associations (Gemeindeverbände). The county governments (Landkreise) do not have general responsibility, but they are public bodies whose responsibilities are defined by the federal and mainly by the provincial (Länder) legislations (Maurer, 2009, pp. 591-592).

The tasks of the county level local governments are very different in the continental Europe which depends on several factors. Firstly, there are continental countries which have three-tier local government systems. The model state of these systems is France ${ }^{22}$. In this model there are two regional local government tiers: the counties and the regions. The spatial structure of France is very fragmented, the majority of the communities (communes) are too small to perform appropriately the local public services. Therefore in the French model the counties (départements) are responsible for the provision of the majority of the basic local public services, and the regions are responsible mainly for the specialized services and they are the main bodies of the regional planning and development (Hoffman, 2012: 333-334). The most similar model to the French system is the Polish and the Bavarian three-tier system (Hoffman, 2011: 26-28).

In Germany the regulation on the local self-governments belongs to the powers of the provinces (Länder). Thus the German counties can be interpreted as an additional, supplementary local government level, which is a correction tool of the spatial fragmentation and the limited (economic and administrative) capacity of the German settlements (Brüning 2013: 70-71). In Germany the counties have significant regional planning and development competences but several regional tasks are performed by inter-municipal cooperation. The most common form of these regional inter-municipal bodies are the planning associations (Planungsverbände) (Schmit-Aßman \& Röhl, 2005, p. 119).

\footnotetext{
${ }^{22}$ Traditionally, Italy and Spain are considered as the follower of this approach but the Italian and the Spanish development in the 1990s and the 2000s resulted different systems. In Italy the regions (regione) have legislative powers, they can pass acts. Thus, the Italian regions have more powers than the local government entities (Mirabella et al., 2012: 258). In Spain the powers of several regions (comunidad autónoma) - for example Catalonia and the Basque Country - have been largely extended, so that these regions can be considered rather a Member State of a Federation than a regional local government (Moreno, 2004: 262 and Rodriguez-Arana, 2008: 203-206).
} 
Hoffman, I.

\section{RESULTS: THE ROLE OF THE COUNTIES IN HUNGARY IN THE FIELD OF REGIONAL DEVELOPMENT - A HISTORICAL OUTLOOK FROM THE 19TH CENTURY TO 2011/12}

The autonomy of the counties has a long history in the Hungarian public administration. Although the self-governance of the counties was recognised by the feudal state, the modern county governments were institutionalised after the bourgeois transformation in Hungary, in the second half of the $19^{\text {th }}$ century. This establishment was linked to the evolvement of the regional development as a policy, as well. Therefore the competences of the counties in the field of regional development were traditionally significant (Hoffman, 2017, p. 56).

\section{The county of the bourgeois era $(1867 / 70$ to $1949 / 50)$}

The modern Hungarian municipal system was based on the system of the feudalism. These entitites were responsible for several main state tasks including the law enforcement, jurisdiction, taxation (Timon, 1910, p. 497). The "Acts of April", the acts of the revolution in 1848 tried to modernise the former feudal county. After the lost War of Independence, the Habsburg neoabsolutism in the 1850s eliminated the self-self-governance of the counties which were replaced by central government agencies (Mezey et al., 1999, p. 341). A new local municipal system was established by the Local Government Acts of 1870 and 1886. By these acts the Hungarian meso level was unified: formerly different meso units were instituionalized as a part of the feudal heritage. The differences of these units remained in the county structure: in Transylvania and in the northern part of Hungary the counties were relatively small and in the Great Hungarian Plain the counties were very large. The counties were divided into districts (járás), which did not have self-governance, they were practically branch offices of the counties. The communities were under the strong supervision of the district administration, their self-governance was strongly limited. The towns have different types: the large towns (county towns - törvényhatósági jogú város - and the Royal Capital of Budapest - Budapest székesföváros) were independent from the counties: they have parctically the same legal status but they exercised the competences of the communities and dsitricts, as well. The small towns (district towns - rendezett tanácsú város) were parts of the counties but they have the legal status of a district.

In the bourgeois era the counties had broad competences. Although the counties have important administrative and public service competences, the regional development was strongly centralised in the $19^{\text {th }}$ century: the development of the transport and the support of 
the industrial production was orgnised by the central government. The counties have other competences of regional development which tasks did not belong to the competences of the central adinistration. The first modern urban area of Hungary, the agglomeration of Budapest has a special development structure. An atypical body was organised, the Council for the Public Works in the Capital which was an intergovernmental body: the members were delegated by the central government and the municipal councils of Budapest and Pest County. This council was responsible for the development and planning of the Greater Budapest Area (Hoffman, 2017, pp. 58-59).

After the Trianon Treaty (which closed the First World War in Hungary) the inequality of the counties became even more prominent. Several large counties remained part of the reduced territory of the Kingdom of Hungary and these counties have not been divided. Several counties became smaller or fragmented, baceuse of the territorial changes. The county system has not been radically reformed. Thus Hungary was divided into 25 counties but the largest county had almost one-eight $(13.72 \%)$ of the country area. This system was strongly criticized by the Hungarian administrative scientists, as well. The main critics was that the seat towns of the counties were not part of the county government, thus the centre and the agglomeration were administratively divided. This problem was significant both in urban and rural areas. The sizes of the county governments were criticized, because there were great differences. $^{23}$

Therefore, in the public administration sciences two main reform concepts were emerged. These concepts had common elements: both of them were based on the unity of the town and the agglomeration. The first one was the town-county concept of Ferenc Erdei which wanted to establish 70 to 80 town centered town-counties - practically unitary authorities of the towns and their agglomerations - instead of the then 25 counties (Erdei, 1939, pp. 233-235). The other concept was a town-centered one, as well, but it did not want to replace the two-tier local government system with a one-tier model: this concept intended to strengthen the districts and the inter-municipal cooperation (Magyary \& Kiss, 1939, pp. 213-219, Magyary, 1942, p. 218). Although several important reform plans were developed between 1928 and 1942, the system did not changed. From 1938 the centralisation of the system was strengthened.

\footnotetext{
${ }^{23}$ Hungary had 25 counties between 1923 and 1938. The average size of the counties were $3723 \mathrm{~km}^{2}$. The largest Hungarian county in the period between 1920 and 1938 was Pest-Solt-Pilis-Kiskun county, and its area was $12767 \mathrm{~km}^{2}$ (the $13,72 \%$ of the whole territory of Hungary).
} 


\section{The counties and the development policy of the communist period (1949/1950-1989/90)}

The local government system of the bourgeois era was swept away by the storm of the World War II. The Hungarian municipal system could not be changed during the democratic era from 1945 to $1947 / 48$, only reform plans were published which were mainly based on the 'town-county' concept of Ferenc Erdei.

The local and territorial public administration was transformed after the adoption of the Stalinist Constitution. After 1949 the Soviet local and regional administration model was introduced in Hungary by the Act I of 1950 on the Councils (the $1^{\text {st }}$ Act on the Councils). This model was based on the concept of the unity of the public administration. The local, the district and county councils did not have self-governance, they were the local and territorial agencies of the central government. The county councils were directed by the Council of the Ministers (which was the government of the People's Republic of Hungary) and by the ministrries and central agencies. Although the councils were only agencies of the central government, they had elected bodies, as well. The county councils have only complementary role in the regional development policy. The development policy was strongly centralised: the former private ownership was primarily abolished, the planned economy was introduced. Therefore the main body responsible for the national, regional and local development was the National Planning Office (Országos Tervhivatal) (Kornai, 1992, p. 111). The strong direction of this system was partly reduced by the Act X of 1954 (the $2^{\text {nd }}$ Act on the Councils). This system was significantly amended by the Act I of 1971 on the Councils (the $3^{\text {rd }}$ Act on Councils). This Act was adopted after the New Economic Mechanism of 1968 by which reform several market economy elements were introduced in the socialist planned economy system. The self-government nature of the councils was recognized by the new Act as the only one among the countries of the Council for Mutual Economic Assistance (CMEA) (Fonyó, 1976, p. 59).

The county councils played a very important role during the communist period. The majority of the agencies of the central government were merged with the county councils which became - as I have above mentioned - the agencies of the central government, as well. Thus, the central role of the counties in the local and regional administration remained. As part of the reform the county system was reorganized in 1950. The number of the counties was reduced from 25 to 19 thus the most significant disparities were eliminated. The strengthening of the county councils was very pronounced by the $3^{\text {rd }}$ Act on the Councils. The $3^{\text {rd }}$ Act on the Councils and the Act II of 1979 on the Public Finance introduced a countycentered local financing and planning system. The funding of the communities was delegated 
to counties, thus, the counties were responsible for sharing the state fund between the communities of the counties (Fonyó, 1976, p. 256). Therefore, the counties became the major bodies responsible for regional development.

\section{The regional development system after the Democratic Transition: the 'floating county'}

During the Democratic Transition there were reform plans which proposed to establish a onetier local government system in Hungary (Csefkó, 1997, p. 81). The main reason of this porpopal was that the county councils were the 'last bastions of the anciene régime'. The counties became very important bodies after the reforms of the 1970s. Thus, a strong 'counter-county' movement evolved. As a compromise the county governments remained but their powers were strongly reduced. The counties became practically subsidiary service providers of the specialized public services. In addition to the limited service provider tasks of the counties the local communities were allowed to take over widely the tasks of the counties by the Act on Local Self-Governments (Hoffman, 2011, pp. 31-32). The majoritiy of the former competences of the authorities directed by the county council were given to the newly organised territorial agencies of the central government. As a result of these reforms, the counties lost their competences in the field of regional development, as well.

The regional development was strongly centralised by the Act LXXXIX of 1992 on the targeted support: the decisions were made by the Parliament and partly by the Government. The reduction of the territory and population of the counties weakened these entities, as well. The county towns (or towns with county rights) were institutionalised by the Act on the Local Self-Governments which were not part of the county government. In 1990 twenty towns with a population of more than 50000 people were declared a town with county rights. Budapest as the Capital City of Hungary remained an independent type of the municipalities (F. Rozsnyai, 2013, p. 48). Therefore the large Hungarian municipalities and their agglomeration became divided administratively (Hoffman, 2017, p. 63). The democratic legitimacy of the county governments was weakened. The members of the county assemblies were elected indirectly, practically by the representative bodies of the communities and towns (Pálné Kovács, 2003, pp. 186-187). Therefore, the significance of the counties was strongly reduced by the legislation of the Democratic Transition.

This new system was interpreted by the literature as the "floating county" (Zongor, 1994, pp. 34-36): the county governments remained, but they were shadows of their former selves. 
Hoffman, I.

\section{From 'floating county' to 'politics county': the partial reform of the development policy during the 1990s}

The limited significance of the county governments was only partially corrected by the Amendment of the Act on Local Self-Governments in 1994. The democratic legitimacy of the counties was strengthened. From 1994 the members of the assembly of the county were directly elected. The county election was based on a proportional system. Thus, the political significance of the county assembly has been strengthened. The officers of the county could perform duties delegated by the central government after the 1994 Amendment (Hoffman, 2009, p. 132). Although the county towns (the unitary authorities) remained independent from the counties, the majority of the members of the county assembly lived in the county seats. Thus, the county towns just theoretically have not had representation in the county assembly, practically the political elite of the county which inhabited the county seat town ruled the assembly (Pálné Kovács, 1997, p. 62). The number of the county towns was increased: the county seat towns became ex lege county towns, thus two county seat towns which had lesser than a population of 50000 people were declared to county town. The tasks of the counties did not changed radically after the Amendment, but the takeover of the functions by the settlements became more complicated.

The regional development policy was transformed in 1996. The trend of the strengthening of the county governments was slowed by the new act. The counties did not become responsible for the regional development and planning. The Act XXI of 1996 on the Regional Development and Land Use Planning (hereinafter Tftv) institutionalised special, hybrid bodies for the tasks of regional development. These new entities were the - originally tripartite - County Development Boards (megyei területfejlesztési tanácsok). Although the president of these boards were the presidents of the county government but only the minority of the members were delegated by the municipalities of the counties. The majority of the members were delegated by the central government and by the economic interest representation bodies. These bodies can be considered as corporative nature central government bodies (Ivancsics, 2007, p. 7). Although the county gvernments were responible for the land use planning in the counties, the regional development was just partly decentralised. This model was just partly amended during the EU Accession. Because of the NUTS 2 based European regional development system, new hybrid bodies, the Regional Development Boards were established (Szabó, 2008, pp. 76-77). The former trilateral structure was transformed. A new two-and-half-lateral model was institutionalised: the interest represenation groups lost their voting rights in these boards, they had only permanent 
invitational status. Thus the influence of the central government was more singnificant in these regional bodies (Pálné Kovács, 2009, pp. 50-51).

Thus, the tasks of the county governments were quite narrow, but they have a strong democratic legitimation therefore the "floating county" became "politics county" (Zongor, 2000: 20).

\section{Reform plans in the first decade of the $21^{\text {st }}$ century}

Having regard to the Accession Process to the EU, the reform plans in the Visegrád Countries were strongly influenced by the structure of the European regional policy (Nemes Nagy, 1997, pp. 4-6). The regionalisation process in the Westeren and Southern European states was impacted these concepts, as well (Pálné Kovács, 2009, pp. 44-46). Therefore the common element of these concepts was the establishment of NUTS-2 level regional governments. The counties were attacked "from below", as well. Several reform plans tried to establish effective inter-municipal service provision framework (Hoffman, 2009, pp. 254-258). The reform plans were based on the self-governance of the regional entities and they agreed that the regional planning should be one of the major tasks of the new bodies. Tha first concept was a provate proposal which was based on the traditional structure of the Hungarian counties. The "greater county' concept of Imre Verebélyi was based on the restructuring and partial merge of the counties. These new 'greater counties' could be NUTS-2 level entities, and they could be responsible for the tasks of regional planning and development, as well (Verebélyi, 2000, pp. 582-585).

Another approach was preferred by the Hungarian governments: they tried to establish new, regional governments instead of the counties. The institutionalisation of these regional entities was an important element of the government program of the first Orbán administration (1998-2002) and the left-wing governments between 2002 and 2010. A Bill on the establishment of the regional local governments (Bill No T/240 of the Parliamentary Term 2006-10) was proposed by the second Gyurcsány administration in 2006. This Proposal wanted to establish Italian type regional local governments - without county level, thus the Hungarian municipal system would remained a two-tier one. This Bill failed. The legal reason of the fall was the lack of required qualified (two-third) majority vote of the Parliament, but practically the reform plans were not truly supported by the Hungarian political elite (Pálné Kovács, 2009, p. 47).

The reform of the county system have taken place after 2010 when the right wing parties had a landslide victory and have a qualified (two-third) majority in the Parliament. 
Hoffman, I.

\section{DISCUSSION: THE NEW ROLES OF THE COUNTY GOVERNMENTS: 'CEREMONIAL COUNTY GOVERNMENT' OR 'DEVELOPER COUNTY GOVERNMENT'}

The legal status of the county governments has been radically transformed by the public administration reforms of 2011/12. The county governments lost the vast majority of their tasks, primarily the local services provider roles, but the regional development tasks have been strenghtened. In the following I would like to review the different stages of the transformation.

\section{The approach of the new Constitution, the Fundamental Law of Hungary}

The politicisation of the county government was strenghtened by the amendment of the election of the county councils in 2010. The new, right wing government - which had a qualified majority support in the Parliament - transformed the Hungarian administrative system. A new constitution, the Fundamental Law of Hungary (published April 25 ${ }^{\text {th }} 2011$ ) was passed. The approach on the local governance changed significantly by the Fundamental Law. Formerly, the municipal tiers and units were defined by the Constitution. The articles 31-35 of the Fundamental Law have just indirect regulation on the number of the levels of the local governments and on the definition of the municipal units. Thus, the two-tier system is just partly guaranteed by the Fundamental Law. The former Constitution interpreted the major compteneces of the municipalities as fundamental rights of these entities which can be limited only by an act passed by a qualified majority. ${ }^{24}$ Although the interpretation of the Constitutional Court partly modified the content of these rules because these municipal fundamental rights were interpreted as competence groups which are relatively defended by the Constitution. ${ }^{25}$

A significant change of the new Constitution was that the municipal asset has been declared public property which serves the performance of the municipal tasks. ${ }^{26}$ Now the Fundamental Law allows the central government to nationalise the municipal asset (without any compensation) if the tasks are not performed by the municipalities (Nagy and Hoffman,

\footnotetext{
${ }^{24}$ See paragraph 1 section 43 and section 44/C of the (multiple amended) Act XX of 1949 on the Constitution of the Republic of Hungary.

${ }^{25}$ The main resolutions of the Constitutional Court on the competence and responsibilities of the local governments are the Res. No. 4/1993 AB (published on February 12 ${ }^{\text {th }}$ ), the Res. No. 47/1991 AB (published on September $24^{\text {th }}$ ), the Res. No. 31/2004 AB (published on September $11^{\text {th }}$ ) and the Res. No. 55/2009 AB (published on May $6^{\text {th }}$ ).

${ }^{26}$ See paragraph 6 article 32 of the Fundamental Law of Hungary (published on 25 ${ }^{\text {th }}$ April 2011): "The assets controlled by municipal governments shall be public property, serving the performance of municipal government tasks."
} 
2012, p. 354). The radical transformation of the counties in 2011/12 was based on these regulations.

\section{The transformation of the county government system in 2011/12}

The debates on the transformation of the county governments begun in 2011. Three models were proposed by the Ministry of Interior. The first concept was based on the status quo. The second one was a modest expansion of the competences in which the counties would have been responsible for the tasks of the regional planning. The third version was counties with narrow competences, in which the counties have just representative and coordinative tasks and the former county services are performed by the county towns and by the County Government Offices (which are the general agencies of the central governments in the counties) (Dobos 2011: 67).

The transformation of the county system was decided before the adoption of the new municipal code. The reform was based on the third porposal: the 'ceremonial county' was chosen, because they lost their service provider roles and their asset, as well. As a part of the consolidation the whole county government debt (184 billion HUF) was assumed by the central government. The loss of the tasks is reflected in the total expenditures of the county governments. The average of the annual total expenditures of the county governments has been reduced from 21857 million HUF (ca. 72. 9 million EUR) to 421 million HUF (ca. 1.3 million EUR) from 2011 to 2012. Thus the annual total expenditure in 2012 was $1.93 \%$ (!) of the annual total expenditure of 2011. (The change of the annual total expenditure is shown by Tab. 1).

Table 1 Annual total expenditures of the county governments in 2011 and 2012

\begin{tabular}{|c|c|c|c|}
\hline & \multirow{2}{*}{$\begin{array}{c}\text { Population of the } \\
\text { county } \\
\text { governments } \\
(2011)^{*}\end{array}$} & $\begin{array}{c}\text { Annual total expenditure of the county } \\
\text { governments (million HUF) }\end{array}$ \\
\cline { 3 - 4 } & 410615 & 3011 & 2012 \\
\hline Bács-Kiskun & 234654 & 10245 & 417 \\
\hline Baranya & 298050 & 32415 & 222 \\
\hline Békés & 521888 & 38429 & n. a.** \\
\hline $\begin{array}{c}\text { Borsod-Abaúj- } \\
\text { Zemplén }\end{array}$ & 213468 & 18208 & 294 \\
\hline Csongrád & 276294 & 25709 & 1508 \\
\hline Fejér & 257875 & 25449 & 274 \\
\hline $\begin{array}{c}\text { Győr-Moson- } \\
\text { Sopron }\end{array}$ & 335341 & 7682 & 315 \\
\hline Hajdú-Bihar & &
\end{tabular}


Table 1 (continued)

\begin{tabular}{|c|c|c|c|}
\hline & \multirow{2}{*}{$\begin{array}{c}\text { Population of the } \\
\text { county } \\
\text { governments } \\
(2011)^{*}\end{array}$} & $\begin{array}{c}\text { Annual total expenditure of the county } \\
\text { governments (million HUF) }\end{array}$ \\
\cline { 3 - 4 } & 253118 & 2011 & 2012 \\
\hline Heves & 312411 & 18593 & n.a.** \\
\hline $\begin{array}{c}\text { Jász-Nagykun- } \\
\text { Szolnok }\end{array}$ & 243658 & 12895 & 308 \\
\hline $\begin{array}{c}\text { Komárom- } \\
\text { Esztergom }\end{array}$ & 164753 & 15812 & 266 \\
\hline Nógrád & 1172518 & 34908 & 252 \\
\hline Pest & 249968 & 29205 & 370 \\
\hline Somogy & 434342 & 34150 & 303 \\
\hline $\begin{array}{c}\text { Szabolcs- } \\
\text { Szatmár-Bereg }\end{array}$ & 196887 & 13506 & 218 \\
\hline Tolna & 180141 & 12152 & 251 \\
\hline Vas & 292192 & n.a.*** & 285 \\
\hline Veszprém & 178242 & 19343 & 1078 \\
\hline Zala & 327706 & 21857 & 421 \\
\hline Average & & & \\
\hline
\end{tabular}

* The county towns are not part of the county local government

** Just the local government decree on the 2013 annual budget is available

*** Just the local government decrees on the 2012 and 2013 annual budgets are available

Source: own editing based on the county government decrees on the annual budget in 2011 and 2012 (the decrees are available on National Legislation Database - www.njt.hu)

The central government tried to compensate the county governments for their lost service provider competences (which were formerly the main tasks of the counties). The regional development competences of the county governments have been significantly strengthened. The County and Regional Development Boards were abolished and the competences of the county boards became the responsibilities of the county governments. The complete powers and duties of the regional development boards could not be received by the county assemblies. The legislation of the EU required NUTS 2 level entities to perform several tasks. After the Regulation 1059/2003/EC the Hungarian counties could be interpreted as typical NUTS 3 level bodies, they cannot be considered as NUTS 2 level entitites. The NUTS 2 units in Hungary are not real administrative units, practically, they are merely statistical and partly development units. Obviously, these units do not have self-governance and elected bodies. Thus, a special regulation has been emerged: those functions which can be performed by NUTS 3 level entities belong to the responsibilities of the county governments and those regional development tasks which should be performed by a NUTS 2 level entity belong to 
the responsibilities of a special body. These special bodies are the regional development consultation forum whose members are the presidents of the county assemblies.

Although the counties became responsible for regional development, the major regional intermediate bodies, the regional development agencies, were then directed by a central government body, by the National Development Agency and by the Ministry for National Development. Thus, the counties received a long list of new competences but they had just limited impact on the allocation of the development funds. The coordination and the direction of the actual development policy remained strongly centralised after 2012 .

These changes were reflected by the rules of the Act CLXXXIX of 2011 on the Local self-Governments of Hungary, as well.

It was very interesting that these reforms have less political consequences than the regional experiments in 2006/2007. One of the main reasons is that the political structure of the county government has remained unchanged (Pálné Kovács, 2016, p. 84.).

\section{The evolvement of the 'developer county'?}

The concept of 'ceremonial county' was partly transformed after 2014. Although the service provider role of the counties was abolished, the regional development tasks were strenghtened. The ownership of the former regional development agencies changed: it was transferred to the county municipalities. These regional development agencies were important intermediate bodies of the regional development funds of the European Union and they had significant planning and coordination competences. They were organised at the NUTS-2 level, therefore after 2013/2014 they were jointly owned by the counties of the given NUTS-2 regions. Therefore, prima facie, the counties became one of the major bodies responsible for regional planning. This prominent role of the county government was just partial. The majority of the sources of the Hungarian regional development funds come from the European regional development and cohesion funds (Medve-Bálint, 2017, p. 282-283). Therefore, the bodies responsible for planning, management, cooridantion and direction of the EU funds have the primary influence on the Hungarian regional development policy. In Hungary these tasks are strongly centralised: from 2014 the main body responsible for the direction and coordination of the EU funds is the Office of the Prime Minister (Miniszterelnökség) ${ }^{27}$ after the Government Decree No. 4 of 2011 (published January $28^{\text {th }}$ ) and Government Decree No. 272 of 2014 (published November $5^{\text {th }}$ ). Thus, the managing authority of the operational programme for regional development (Területfejlesztés Operatív Program - TOP) is the

\footnotetext{
${ }^{27}$ The Prime Minister's Office is defined as a ministry by the Hungarian law: it is not only the secretariat of the Government, but it has traditional ministerial tasks, as well (Fazekas, 2017, pp. 165-166).
} 
Ministry for National Ecomomy and the managing authority of the programme for rural development (Vidékfejlesztési Program - VP) is the Prime Minister's Office (Hoffman, 2017, p. 104).

The county land use and development plans are regulated by innormative decisions of the county governments (by normative resolutions and county government decrees). But the decision-making process of the regional plans are controlled strongly by the ministries and the agencies after the Government Decree and No. 218 of 2009 (published October $6^{\text {th }}$ ) (Hoffman, 2017, pp. 97-98).

Thus, the counties seemed to be the central player of the Hungarian regional and rural development, but the central government and its agencies have key competences in these fields. The role of the counties have been weakened between 2016 and 2017. Six from the seven regional development agencies were abolished. The former intermediate body tasks of these agencies baceme the competences of the county directorates of the Hungarian State Treasury (which is an agency directed by the Ministry for National Economy). Just several coordination and planning competences of the regional development agencies were transferred to the offices of the county governments.

Therefore the development competencies of the county government have been partially strengthened after 2014. But the Hungarian regional development system remained a strongly centralised one, and the role of the counties is important but not decisive in this field. This strengthening is mirrored by the change of the annual total expenditures of the county governments. The expenditures increased but this growth was just modest (see Tab. 2).

Table 2 Annual total expenditures of the county governments in 2011, 2012 and 2017

\begin{tabular}{|c|c|c|c|}
\hline \multirow{2}{*}{ County } & \multicolumn{3}{|c|}{ Annual total expenditure of the county local governments } \\
& 2011 & 2012 & 2017 \\
\cline { 2 - 4 } & 30399 & 417 & 660 \\
\hline Bács-Kiskun & 10245 & 222 & 725 \\
\hline Baranya & 32415 & n. a.** & 341 \\
\hline Békés & 38429 & 343 & 1124 \\
\hline $\begin{array}{c}\text { Borsod-Abaúj- } \\
\text { Zemplén }\end{array}$ & 18208 & 294 & 650 \\
\hline Csongrád & 25709 & 1508 & 537 \\
\hline Fejér & 25449 & 274 & 545 \\
\hline $\begin{array}{c}\text { Györ-Moson- } \\
\text { Sopron }\end{array}$ & 7682 & 315 & 641 \\
\hline Hajdú-Bihar & 14325 & n.a.** & 528 \\
\hline Heves & &
\end{tabular}


Table 2 (continued)

\begin{tabular}{|c|c|c|c|}
\hline \multirow{2}{*}{ County } & \multicolumn{3}{|c|}{ Annual total expenditure of the county local governments } \\
& 2011 & 2012 & 2017 \\
\cline { 2 - 4 } & 18593 & 308 & 657 \\
\hline $\begin{array}{c}\text { Jász-Nagykun- } \\
\text { Szolnok }\end{array}$ & 12895 & 266 & 409 \\
\hline $\begin{array}{c}\text { Komárom- } \\
\text { Esztergom }\end{array}$ & 15812 & 252 & 386 \\
\hline Nógrád & 34908 & 452 & 622 \\
\hline Pest & 29205 & 370 & 760 \\
\hline Somogy & 34150 & 303 & 903 \\
\hline $\begin{array}{c}\text { Szabolcs-Szatmár- } \\
\text { Bereg }\end{array}$ & 13506 & 218 & 580 \\
\hline Tolna & 12152 & 251 & 665 \\
\hline Vas & n.a. & 285 & 752 \\
\hline Veszprém & 19343 & 1078 & 479 \\
\hline Zala & 21857 & 421 & 630 \\
\hline Average & coun & & \\
\hline
\end{tabular}

Source: own editing based on the county government decrees on the annual budget in 2011, 2012 and 2017 (the decrees are available on National Legislation Database - www.njt.hu)

\section{CONCLUSION}

The Hungarian counties have traditionally important competencies in the field of regional planning and development. Although they have had significant competences, the characteristic of the Hungarian regulation have been a centralised one. These tasks have been transformed several times in the last one-and-half century. The last three decades were an eventful period. The regional development system of the late Communist period was based on the counties. During the Democratic Transition they lost their development tasks and became additional human service providers. They were partially 'rehabilitated' during the mid 1990s. This role was significantly transformed after 2011: the counties lost their service provider competences, but they received several development and planning tasks. Although the concept of the 'developer county' was highlighted and the list of these planning and development competences is broad, the centralised regional planning and development model remained. The decisive competences in the field of regional planning and development belong to the ministries and the agencies of the central government.

\section{Acknowledgement}

This article was supported by the János Bolyai Research Scholarship of the Hungarian Academy of Sciences.

\section{REFERENCES}


Arden, A., Baker, C. \& Manning, J. (2009). Local Government Constitutional and Administrative Law. London: Sweet \& Maxwell

Bailey, S. H. (1983). Central and Local Government and the Courts. Public Law 28 (1), 8-16.

Bernard, P. (1983). L' État et la décentralisation. Du préfet au Commissaire de la République. Paris : La Documentation française)

Bowman, A. O', \& Kearney, R. (2012). State and Local Government. Boston: Wadsworth

Brüning, C. (2013). Kommunalrecht. In Ehlers, D., Fehling, M. \& Pünder, H. (eds.): Besonderes Verwaltungsrecht. Band 3. Kommunalrecht, Haushalts- und Abgabenrecht, Ordnungsrecht, Sozialrecht, Bildungsrecht, Recht des öffentlichen Dienstes (pp. 175).Heidelberg: C. F. Müller

Callanan, M. (2003). Regional Authorities and Regional Assemblies. In Callanan, M. Keogan, J. F. (eds.) Local Government in Ireland. Inside Out (pp. 429-446). Dublin: Institute of Public Administration

Clawson, M. (2011). Suburban Land Conversion int he United States. An Economic and Governmental Process. New York: Earthscan

Cowie, P., Madanipour, A., Davoudi, S. \& Vigar, G. (2016). Maintaining stable regional territorial governance institutions in times of change: Greater Manchaster Combined Authority. In Schmitt, P. \& van Well, L. (eds.). Territorial Governance across Europe. Pathways, Practices and Prospects (pp. 141-156). London: Routledge

Csefkó, F. (1997). A helyi önkormányzati rendszer. Budapest \& Pécs: Dialóg Campus Kiadó

Dobos, G. (2011). Elmozdulás középszinten: A 2010-es önkormányzati választási reform hatásai a megyei önkormányzatokra. Politikatudományi Szemle 20 (4), 61-83.

Elliott, M. \& Thomas, M. (2017). Public Law. Oxford: Oxford University Press

Erdei, F. (1939). A magyar város. Budapest: Athenaeum

Fonyó, G. (ed.) (1976). A tanácstörvény magyarázata. Budapest: Közgazdasági és Jogi Könyvkiadó

F. Rozsnyai, K. (2013). A területszervezésre vonatkozó szabályok a Mötv.-ben. Új Magyar Közigazgatás 6 (7-8), 37-48

Fazekas, J. (2017). Központi államigazgatási szervek. In: Fazekas M. (ed.) Közigazgatási jog. Általános rész I. (pp. 145-186). Budapest: ELTE Eötvös

Hoffman, I. (2009). Önkormányzati közszolgáltatások szervezése és igazgatása. (Budapest: ELTE Eötvös Kiadó)

Hoffman, I. (2011). A helyi önkormányzatok társulási rendszerének főbb vonásai. Új Magyar Közigazgatás 4 (1), 24-34.

Hoffman, I. (2012). Some Thoughts on the System of Tasks of the Local Autonomies Related to the Organisation of Personal Social Care. Lex localis - Journal of Local SelfGovernment, 10, 323-340.

Hoffman, I. (2017). Bevezetés a területfejlesztési jogba. Budapest: ELTE Eötvös

Ivancsics, I. (2007). Atipikus szervek a területi közigazgatásban. Közigazgatási Szemle, 1(1), 4-15.

Kornai, J. (1992). The Socialist System. The Political Economy of Communism. Oxford: Oxford University Press

Magyary, Z. (1942). Magyar közigazgatás. Budapest: Királyi Magyar Egyetemi Nyomda

Magyary, Z. \& Kiss, I. (1939). A közigazgatás és az emberek. Ténymegállapító tanulmány a tatai járás közigazgatásáról. Budapest: Magyar Közigazgatástudományi Intézet 
Maurer, H. (2009). Allgemeines Verwaltungsrecht. München: Verlag C. H. Beck

Medve-Bálint, G. (2017). Funds for wealthy and politically loyal? How EU funds may contribute to increasing regional disparities in East Central Europe? In Bachtler, J., Berkowitz, P., Hardy, S. \& Muravska, T. (eds.) EU Cohesion Policy. Reassessing Performance and Direction (pp. 271-300). Abingdon (UK) - New York (NY, USA): Routledge

Mezey, B. (ed.) (1999). Magyar alkotmánytörténet. (Budapest: Osiris)

Mirabella, M., Altieri, A., \& Zerman, P. M. (2012). Manuale di diritto amministrativo. Milano: Giuffré Editore

Moreno, L. (2004). La federalización autonómica. In: Chust, M. (ed.). Federalismo y cuestión federal España (pp. 237-266). Castelló de la Plana: Publicacions de la Universitat Jaume I

Morphet, J. (2008). Modern Local Government. London: SAGE

Nagy, M., \& Hoffman, I. (2012). A Magyarország helyi önkormányzatairól szóló törvény magyarázata. Budapest: HVG-Orac

Nemes Nagy, J. (1997). Régiók, regionalizmus. Educatio, 6 (3), 1-18.

O'Sullivan, T. (2003). Local Areas and Structures. In: Callanan, M. \& Keogan, J. F. (eds.). Local Government in Ireland. Inside Out (pp. 41-81). Institute of Public Administration: Dublin

Pálné Kovács, I. (1997). Lokális és regionális politika. Politikatudományi Szemle, 6 (2), 4769.

Pálné Kovács, I. (2003). A területi érdekérvényesítés átalakuló eszközei. Politikatudományi Szemle, 12 (4), 167-191.

Pálné Kovács, I. (2009). Régiók és fejlesztési koalíciók Politikatudományi Szemle, 18 (4), 37-60.

Pálné Kovács, I. (2016). A magyar területi közigazgatási reformok főbb állomásai. In Pálné Kovács, I. (ed.) A magyar decentralizáció kudarca nyomában (pp. 73-85) Budapest \& Pécs: Dialóg Campus

Rodriguez-Arana, J. (2008). Derecho administartivo español. Tomo I. Introducción al derecho administrativo constitucional. Oleiros: Netbiblo

Schmidt-Aßmann, E. \& Röhl, H. C. (2005). Kommunalrecht. In Schmidt-Aßmann, E. (ed.): Besonderes Verwaltungsrecht (pp. 1-120). Berlin: Walter de Gruyter

Szabó, P. (2008). A térszerkezet fogalma, értelmezései. Tér és Társadalom, 22 (4), 63-80.

Timon, Á. (1910). Magyar alkotmány- és jogtörténet. Budapest: Hornyánszky Viktor Könyvkiadóhivatala

Verebélyi, I. (2000). Önkormányzati rendszerváltás és modernizáció II., Magyar Közigazgatás, 50, 577-587.

Zongor, G. (1994). A lebegő megye. In Agg Z. (ed.). A lebegő megye (pp. 14-42). Veszprém: Comitatus Kiadó

Zongor, G. (2000). A lebegő megyétől a politizáló megyéig. Comitatus, 10 (9), 17-23. 